Original Article

Artigo Original

Andréia Cristina Muznlinger dos Santos ${ }^{1}$ Maria Cristina de Menezes Borrego ${ }^{2}$

Mara Behlau²

Keywords

Voice

Voice Training

Speech, Language and Hearing Sciences

Speech Acoustics

Auditory Perception

Descritores

Voz

Treinamento da Voz

Fonoaudiologia

Acústica da Fala

Percepção Auditiva

Correspondence address:

Andréia Cristina Muznlinger dos Santos

Rua Trinta e Três, Qdr. 81, 15, Santa Cruz II,

Cuiaba (MT), Brasil, CEP: 78077-015.

E-mail: andreia@fonomt.com.br

Received: $12 / 17 / 2014$

\section{Effect of direct and indirect voice training in Speech-Language Pathology and Audiology students}

\author{
Efeito de treinamento vocal direto e \\ indireto em estudantes de Fonoaudiologia
}

\begin{abstract}
Purpose: To verify the effect of two approaches of vocal training in Speech Language Pathology and Audiology students, a direct and an indirect approach. Methods: Participants were 25 female Speech Language Pathology and Audiology students divided into two groups: direct training with vocal exercises, DTG ( $n=13)$; and indirect training with vocal orientations, ITG $(n=12)$. The training sessions were conducted by the same speech language pathologist in six weekly sessions of 30 minutes. Both groups underwent multidimensional voice assessment, pre- and post-training: vocal self-assessment; Vocal Symptoms Scale (VSS); auditory perceptual analysis of sustained vowel and connected speech; acoustic analysis of voice through the Vocal Range Profile (VRP) and Speech Range Profile (SRP); and Group Climate Questionnaire, only at the end of training. Results: The DTG showed changes in auditory perceptual analysis of vowel, which was less diverted after training; and expansion of the voice range in the VRP and SRP, which proves best vocal performance. However, the ITG showed no changes in any of the parameters evaluated. In Group Climate, the ITG obtained the highest conflict score in comparison to the DTG, probably because the indirect approach did not favor exchange in the group and did not allow a better quality interaction. Conclusion: The direct approach provided greater benefits to students than the indirect approach, with significant change in voice quality, and can serve as inspiration to Speech Language Pathology and Audiology courses to prevent dysphonia.
\end{abstract}

\section{RESUMO}

Objetivo: Verificar o efeito de duas abordagens de treinamento vocal em estudantes de Fonoaudiologia, uma direta e outra indireta. Métodos: Participaram 25 estudantes de Fonoaudiologia, do gênero feminino, divididas em dois grupos: treinamento direto com exercícios vocais - GTD ( $n=13)$, e treinamento indireto com orientações vocais - GTI ( $\mathrm{n}=12)$. Os treinamentos foram conduzidos pela mesma fonoaudióloga em seis sessões, com frequência de uma sessão de 30 minutos por semana. Ambos os grupos passaram por avaliação multidimensional da voz, pré e pós-treinamento: autoavaliação vocal; Escala de Sintomas Vocais (ESV); análise perceptivo-auditiva da vogal sustentada e da fala encadeada; análise acústica da voz por meio do Perfil de Extensão Vocal (PEV) e Perfil de Extensão de Fala (PEF); e questionário de Clima de Grupo, este somente ao final do treinamento. Resultados: O GTD apresentou modificações para: análise perceptivo-auditiva da vogal, que ficou menos desviada após o treinamento; ampliação da extensão de voz no PEV e PEF, o que comprova melhor rendimento vocal. Porém, o GTI não mostrou mudanças em nenhum parâmetro avaliado. No Clima de Grupo, o GTI obteve maior escore conflito do que o GTD, pois provavelmente a abordagem indireta não favoreceu trocas no grupo e não permitiu uma interação de melhor qualidade. Conclusão: A abordagem direta proporcionou maiores benefícios às estudantes do que a abordagem indireta, com modificação significativa da qualidade vocal, e pode servir de inspiração aos cursos de Fonoaudiologia a fim de prevenir as disfonias.

Study carried out at the Department of Speech Language Pathology and Audiology of Centro Universitário de Várzea Grande - UNIVAG - Várzea Grande (MT) and at the Center for Voice Studies - CEV - São Paulo (SP), Brazil.

(1) Centro Universitário de Várzea Grande - UNIVAG - Várzea Grande (MT), Brazil.

(2) Universidade Federal de São Paulo - UNIFESP; Center for Voice Studies - CEV - São Paulo (SP), Brazil. Conflict of interests: nothing to declare. 


\section{INTRODUCTION}

The speech language pathologist is a voice professional who works with research, prevention, evaluation, and speech language therapy in the fields of oral and written communication, speech and hearing, as well as improvement of speech and voice patterns ${ }^{(1)}$.

The preferred voice quality of the speech language pathologist is characterized as an adapted voice, with balanced resonance, isochronic vocal attack, stable emission, tended to increase in frequency and intensity, and large use of modulation $^{(2,3)}$.

However, studies showed the presence of complaints and vocal alterations since graduation. Students reported the following symptoms: general fatigue, hoarseness, irritation in the larynx, low pitch, breathiness, straining, frequency breaks, and resonance changes ${ }^{(4,5)}$. The prevalence of voice disorders was reported by $12 \%$ of future speech language pathologists, and such index is greater than in the general population $(3-9 \%)^{(5)}$.

Aware of the risk and high vocal demand, Speech Language Pathology and Audiology undergraduates have been inserted successfully in voice and speech training programs $s^{(6,7)}$. However, there is a difficulty in comparing the results of the approaches used in the various training programs for future professionals due to the different methods used.

According to the literature ${ }^{(8,9)}$, there are three main approaches to improving the communication patterns that can prevent voice problems: direct approach, consisting of vocal exercises; indirect approach, consisting of vocal hygiene guidelines; and combined interventions (direct and indirect approaches).

The direct and indirect approaches have extremely opposite characteristics because the first acts directly on the voice, and the second, on the learning of vocal self-care ${ }^{(13,14)}$. However, in Speech Language Pathology and Audiology students, little is known about the comparative effect of these approaches and their contributions to the academic training in the field of voice.

According to the literature, voice training is usually applied in a group, as it is targeted at people who have a common goal, and its efficacy is scientifically proven and it has reduced costs to society ${ }^{(15-17)}$. However, there are no reports in the literature on the impacts of direct and indirect approaches on the vocal dynamics developed by vocal training groups.

The group dynamics were initially investigated in psychology by Mackenzie ${ }^{(18)}$, which classified the group interactions in three types of group climate: engagement, conflict, and avoidance. In the field of Speech Language Pathology and Audiology, group climate was studied in a group of teachers, who were part of a vocal therapy program, and it was noted that positive group interaction with engaged subjects provided significant improvements in quality of life, facilitated the adherence to the intervention, and assisted in the reduction of vocal symptoms ${ }^{(19)}$. However, when a group is conflictive, there may be rejection and lack of trust, which can produce a negative result ${ }^{(18)}$. Finally, little is known whether the different types of voice training approaches can also modify the dynamics developed by the intervention groups.
Thus, this study aimed to evaluate the effect of two vocal approaches in groups of Speech Language Pathology and Audiology students, a direct approach and an indirect approach.

\section{METHODS}

This study was approved by the research ethics committee of Universidade Federal de Mato Grosso, Campus Araguaia, under protocol no. $347753 / 13$, and all participants signed the informed consent.

The study included 25 volunteer Speech Language Pathology and Audiology students, female, randomly divided into two groups: direct approach training group - DTG $(n=13)$, with individuals aged $18-41$ years (mean $=24.46$ years); and indirect approach training group - ITG $(\mathrm{n}=12)$, with students aged $18-37$ years (mean $=24.41$ years). Both trainings were directed by the same speech language pathologist in six sessions, with frequency of a 30-minute session per week, called session 1 (S1), session 2 (S2), session 3 (S3), session 4 (S4), session 5 (S5), and session 6 (S6).

The DTG was subjected only to vocal exercises (Chart 1):

- (S1) vocal warm-up;

- (S2) vocal warm-up and cool-down;

- (S3 and S4) vocal warm-up and glottal source exercises; and

- (S5 and S6) vocal warm-up, articulation, breathing, emphasis, and vocal modulation.

The ITG was subjected only to vocal hygiene guidelines (Chart 2):

- (S1) laryngeal anatomy;

- (S2) vocal physiology and production;

- (S3) most common voice disorders;

- (S4) negative attitudes that lead to vocal problems; and

- (S5 and S6) positive attitudes aimed at healthy vocal habits.

All subjects underwent a multidimensional voice assessment, pre- and post-intervention, held on the first and last day of training, respectively:

1. vocal self-assessment;

2. Vocal Symptoms Scale (VSS) $)^{(20,21)}$;

3. auditory perceptual analysis;

4. acoustic analysis by recording the sustained vowel $/ \varepsilon /$ and counting of numbers from 20 to 30; and

5. Group Climate Questionnaire ${ }^{(18)}$, only on the last day of training.

In the vocal self-assessment, the student should classify their voice quality, through a five-point Likert scale, for the following responses: "excellent," "good," "fair," "poor," and "very poor.

The VSS ${ }^{(20,21)}$, the translated and culturally adapted and validated version for Brazilian Portuguese of the VoiSS protocol, was used for mapping vocal signs and symptoms. It consists of a 30-question questionnaire divided into three domains: limitation (15 questions), emotional (eight), and physical (seven). Each question is scored from zero to four, according to the frequency of occurrence in "never," "rarely," "sometimes," "often," and "always," with scores calculated by simply adding the points. The higher the score in this protocol, the greater 
Chart 1. Vocal training program of the direct approach vocal training group with Speech Language Pathology and Audiology undergraduates

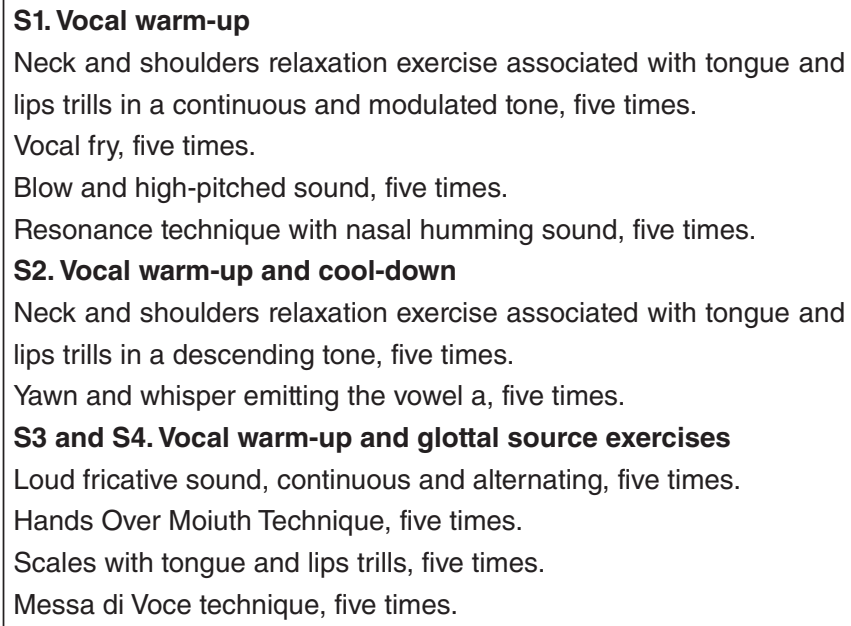

S5 and S6. Vocal warm-up, articulation, breathing, emphasis, and vocal modulation exercises

Overarticulation of the days of the week and months of the year, two times.

Counting from 1 to 30 with a cork between the teeth, one time.

Speaking tongue twisters through diadochokinesis and phrases.

Breathing in and out five times, observing the lower and the lateral expansion of the ribs.

Breathing in and out emitting a fricative sound for as long as possible, five times, continuously and alternately.

Breathing in and out speaking short, medium, and long sentences, coordinating speech and breathing.

Reading phrases in a modulated form for affirmation, question, and exclamation.

Reading a phrase modifying the emphasis according to the target word, four times.

Reading the text "Meeting at the Company", using the emphasis and modulation capabilities.

Source: Voz: O Livro do Especialista - Volume II(24) and Muito além do ninho de mafagafos: um guia de exercícios práticos para aprimorar sua comunicação(25).

is the perception of the overall level of voice alteration regarding the limitations in the use of the voice, emotional reactions, and physical symptoms.

In the auditory perceptual analysis, the samples were recorded and edited using VoxMetria software, version 4.4. (CTS Informática). For the analysis of the sustained vowel/ع/, the first and the last second of emission were eliminated, as they are marked by natural instability, and only the remaining seconds were analyzed; and, for the number count from 20 to 30 , the original recording lengths were kept.

The auditory perceptual analysis was performed by three speech language pathologists who are voice experts, in two sequential listening sessions of the recordings in random order, the first with the sustained vowels and the second with the connected speech. Samples were tested in the field and simultaneously to the three evaluators, who could listen to them as often as deemed necessary. There was repetition of $10 \%$ of the stimuli to verify the intra-rater reliability.
Chart 2. Vocal training program of the indirect approach vocal training group with Speech Language Pathology and Audiology undergraduates

\section{S1. Laryngeal anatomy}

Components of the larynx - cartilage; laryngeal muscles; ligaments, joints, and laryngeal membranes.

Histological anatomy of the vocal fold.

Main vocal parameters - intensity and frequency.

S2. Vocal physiology and production

Physiology of phonation.

Voice and speech production.

Vocal psychodynamics.

\section{S3. Most common voice disorders}

Classification of dysphonia.

Vocal signs and symptoms.

Professionals responsible voice treatment.

S4. Negative attitudes that lead to vocal problems

Inadequate lifestyles - smoking and alcoholism.

Inadequate vocal habits - shouting, speaking too much, speaking for too long, straining while speaking; not articulating words well, speech in competition with noise.

Other inappropriate behaviors - use of tablets/sprays and not hydrating.

S5 and S6. Positive attitudes aimed at healthy vocal habits

Healthy lifestyle - exercise, balanced diet, hydration.

Appropriate vocal habits - dosing speech time, dosing tone of voice (low-high), dosing the volume of voice (strong-weak).

Source: Voz: O Livro do Especialista - Volume I(26); Voz: O Livro do Especialista Volume III (24).

In the auditory perceptual analysis of the sustained vowel, the judges evaluated the emission of the sustained vowel according to the GRBASI Scale ${ }^{(22)}$, in which the parameters general level of dysphonia, roughness, breathiness, asthenia, strain, and instability were analyzed on a scale of 0 to $3(0=$ no deviation and $3=$ severe deviation). When analyzing the number count from 20 to 30, judges should listen to each pair of stimuli and note which emission they classified as the "best emission." Then they should point out which parameter(s) best justified their choice: voice quality, articulation and pronunciation, loudness, pitch, resonance, speech rate, pneumophonoarticulatory coordination, use of emphasis, and modulation.

In the acoustic analysis, the samples were recorded on the Vocal Grama software, version 4.4 (CTS Informática). The Vocal Range Profile (VRP) and the Speech Range Profile (SRP) ${ }^{(23)}$ were analyzed on the following parameters: minimum and maximum fundamental frequency, semitone range, minimum and maximum intensity, and area. For the evaluation of the VRP, the vowel /E/ was used in ascending and descending glissando and in strong and weak intensity. For the analysis of the SRP, the number count from 20 to 30 in average, weak, strong, and very strong intensity levels.

The voices were recorded in a room with ambient noise below $50 \mathrm{~dB}$, with participants seated, using the Karsect HT-9 microphone and an Andrea PureAudio ${ }^{\mathrm{TM}}$ USB-SA adapter, positioned at an angle of $45^{\circ}$ at a distance of $5 \mathrm{~cm}$ from the 
participant's mouth. The voices were recorded directly onto a Sony Vaio computer, model PCG-31311X.

The Group Climate Questionnaire, also called Group Climate Questionnaire - Short Form (GCQ-S) ${ }^{(18)}$, was translated and culturally adapted into Brazilian Portuguese by the authors, comparing the group climate of the two vocal training groups (Appendix 1). It was originally created for use in psychotherapy groups to check the effects of group climate in treatment outcomes. It consists of a 12-question questionnaire divided into three scales: engagement (five questions), conflict (three), and avoidance (four). Each question is scored from 0 (not at all) to 6 (fully), with scores calculated by simply adding the points.

Statistical analysis of variables was performed using the Statistical Package for Social Sciences software, version 17.0. The Test for Equality of Proportions and the Mann-Whitney's test were applied at a 5\% significance level for comparison of results for groups.

\section{RESULTS}

There were no changes in the vocal self-assessment parameters (Table 1) and in the VSS (Table 2) for any of the two groups. As for the auditory perceptual assessment, significant differences were observed only for the DTG for the analysis of the sustained vowel (Table 3 ) and no change for both groups were observed in the auditory perceptual analysis of speech (Table 4). Significant differences were observed only for the DTG for the VRP and SRP (Table 5).

In the auditory perceptual analysis of the sustained vowel (Table 3), the DTG showed a reduction in voice deviations in the overall score and breathiness parameters, which went from moderate to mild.

In the acoustic analysis of the VRP and SRP (Table 5), an increase was observed in the amplitude of maximum frequency and frequency range in the DTG. An increase in semitone range in the SRP was also observed.

The analysis of the Group Climate Questionnaire responses (Figure 1) showed that the ITG had high scores for all the scales evaluated, but the conflict score was significant when compared to the DTG.

Table 1. Measures of the vocal self-assessment scores

\begin{tabular}{|c|c|c|c|}
\hline Groups & $\begin{array}{c}\text { Pre-training } \\
\mathrm{n}(\%)\end{array}$ & $\begin{array}{c}\text { Post-training } \\
\mathrm{n}(\%)\end{array}$ & $\mathrm{p}$-value \\
\hline \multicolumn{4}{|l|}{ DTG } \\
\hline Excellent & $2(15.4)$ & $1(7.7)$ & 0,539 \\
\hline Good & $9(69.2)$ & $8(61.5)$ & 0.680 \\
\hline Fair & $2(15.4)$ & $4(30.8)$ & 0,352 \\
\hline Poor & $0(0.0)$ & $0(0.0)$ & 1.000 \\
\hline \multicolumn{4}{|l|}{ ITG } \\
\hline Excellent & $1(8.3)$ & $2(16.7)$ & 0,537 \\
\hline Good & 7 (58.3) & $9(75.0)$ & 0,386 \\
\hline Fair & $3(25.0)$ & $1(8.3)$ & 0,273 \\
\hline Poor & 1 (8.3) & $0(0.0)$ & 0,307 \\
\hline
\end{tabular}

*Significant values $(p<0.05)$ - Test of Equality of Proportions

Caption: $\mathrm{DTG}=$ direct training group; $\mathrm{ITG}=$ indirect training group

\section{DISCUSSION}

This study examined the effect of two vocal training approaches, a direct approach and an indirect approach, among Speech Language Pathology and Audiology students ${ }^{(24-26)}$. Different results were found according to the type of approach used for some of the parameters. The direct approach training group presented less voice deviations in the auditory perceptual evaluation of the sustained vowel, maximum frequency range in the VRP and the SRP, and range of the scope of frequencies in the SRP. The indirect approach training group showed no changes in the evaluated parameters.

A literature review ${ }^{(27)}$ on the impacts of vocal training in voice professionals showed that in 9 of 10 studies investigated, the results showed significant changes in vocal quality in this population, with improvement in at least one of the measures related to vocal production when compared to the pre-training assessment data.

No significant changes were observed in vocal self-assessment for both groups when comparing the pre- and post-training moments (Table 1). However, there was a change for the better (although not significant) in the "fair" and "good" classifications in the ITG and "poor" in the DTG, and a change for the worse can also be seen in the "excellent" variable in the DTG group. Thus, the findings suggest that both training approaches caused a change in vocal perception, but not enough to produce

Table 2. Measures of the Vocal Symptoms Scale scores

\begin{tabular}{|c|c|c|c|c|c|}
\hline & Mean (SD) & Median & Min-Max & $\mathrm{Cl}$ & $\mathrm{p}$-value \\
\hline \multicolumn{6}{|l|}{ DTG $(n=13)$} \\
\hline \multicolumn{6}{|l|}{ Limitation } \\
\hline Pre-training & $6.5(7.0)$ & 3 & $1.0-10.0$ & 3,78 & \multirow{2}{*}{0,878} \\
\hline Post-training & $6.2(6.6)$ & 4 & $2.0-9.0$ & 3,57 & \\
\hline \multicolumn{6}{|l|}{ Emotional } \\
\hline Pre-training & $0.6(1.9)$ & 0 & $0.0-0.0$ & 1,05 & \multirow{2}{*}{0,180} \\
\hline Post-training & $0.3(1.1)$ & 0 & $0.0-0.0$ & 0,6 & \\
\hline \multicolumn{6}{|l|}{ Physical } \\
\hline Pre-training & $4.3(2.2)$ & 5 & $3.0-6.0$ & 1,18 & \multirow{2}{*}{0,166} \\
\hline Post-training & $5.4(3.6)$ & 4 & $2.0-8.0$ & 1,94 & \\
\hline \multicolumn{6}{|l|}{ Total } \\
\hline Pre-training & $11.4(9.8)$ & 10 & $3.0-17.0$ & 5,3 & \multirow{2}{*}{0,478} \\
\hline Post-training & $11.9(10.2)$ & 9 & $4.0-17.0$ & 5,6 & \\
\hline \multicolumn{6}{|l|}{ ITG (n=12) } \\
\hline \multicolumn{6}{|l|}{ Limitation } \\
\hline Pre-training & $12.6(7.6)$ & 13,5 & $5.8-17.5$ & 4,3 & \multirow{2}{*}{0,719} \\
\hline Post-training & $13.3(8.6)$ & 12 & $7.8-16.5$ & 4,84 & \\
\hline \multicolumn{6}{|l|}{ Emotional } \\
\hline Pre-training & $0.8(1.4)$ & 0 & $0.0-1.3$ & 0,79 & \multirow{2}{*}{0,197} \\
\hline Post-training & $1.3(1.7)$ & 0,5 & $0.0-2.0$ & 0,98 & \\
\hline \multicolumn{6}{|l|}{ Physical } \\
\hline Pre-training & $6.5(3.9)$ & 7 & $4.3-9.0$ & 2,23 & \multirow{2}{*}{0,090} \\
\hline Post-training & $7.5(3.0)$ & 8 & $4.8-9.0$ & 1,71 & \\
\hline \multicolumn{6}{|l|}{ Total } \\
\hline Pre-training & $19.9(11.6)$ & 20,5 & $9.8-28.0$ & 6,6 & \multirow{2}{*}{0,284} \\
\hline Post-training & $22.1(11.2)$ & 20,5 & $14.0-27.3$ & 6,4 & \\
\hline
\end{tabular}

*Significant values $(p<0.05)$ - Mann-Whitney's test

Caption: $\mathrm{DTG}=$ direct training group; $\mathrm{ITG}$ = indirect training group; $\mathrm{SD}=$ standard deviation; $\mathrm{Cl}=$ confidence interval 
a differentiation between the approaches used. Students may have had difficulties in understanding their own vocal modifications resulting from training through auditory perception. Researchers ${ }^{(28)}$ noted the difficulty faced by Speech Language Pathology and Audiology students in analyzing vocal parameters and advised them through an auditory training targeted to undergraduate students.

Table 2 shows that both groups scored high on the VSS compared to the findings in the Brazilian population without dysphonia, which presented as normal scores equal to or less than 3.77 in the limitation score, 0.32 in the emotional score, 3.02 in the physical score, and 7.11 for the total score ${ }^{(21)}$. In addition, a trend of worsening was noted, even though not statistically significant, in the vocal symptoms among students in post-training moment. This may be linked to aspects related to vocal use and abuse of a young group of university students, which deserves investigation and future orientation because, after all, they must be prepared to face the professional demand soon. Vocal symptoms were also reported by $29 \%$ of the Speech

Table 3. Measures of the scores of the auditory perceptive evaluation of the sustained vowel through the GRBASI Scale

\begin{tabular}{|c|c|c|c|c|c|c|}
\hline & \multicolumn{3}{|c|}{ DTG } & \multicolumn{3}{|c|}{ ITG } \\
\hline & $\begin{array}{l}\text { Pre- } \\
\text { training }\end{array}$ & $\begin{array}{l}\text { Post- } \\
\text { training }\end{array}$ & $p$-value & $\begin{array}{c}\text { Pre- } \\
\text { training }\end{array}$ & $\begin{array}{l}\text { Post- } \\
\text { training }\end{array}$ & $p$-value \\
\hline & n (\%) & n (\%) & & n (\%) & n (\%) & \\
\hline \multicolumn{7}{|c|}{ General level of dysphonia } \\
\hline Normal & $1(2.6)$ & $2(5.1)$ & 0,556 & $0(0.0)$ & $0(0.0)$ & 1.000 \\
\hline Mild & $21(53.8)$ & $31(79.5)$ & $0.016^{*}$ & $20(55.6)$ & $21(58.3)$ & 0,812 \\
\hline Moderate & $16(41.0)$ & $5(12.8)$ & $0.005^{*}$ & $13(36.1)$ & $14(38.9)$ & 0,808 \\
\hline Severe & $1(2.6)$ & $1(2.6)$ & 1.000 & $3(8.3)$ & $1(2.8)$ & 0,303 \\
\hline \multicolumn{7}{|l|}{ Roughness } \\
\hline Normal & $18(46.2)$ & $19(48.7)$ & 0,821 & $14(38.9)$ & $17(47.2)$ & 0,475 \\
\hline Mild & $17(43.6)$ & $15(38.5)$ & 0,645 & $15(41.7)$ & $12(33.3)$ & 0,465 \\
\hline Moderate & $4(10.3)$ & $5(12.8)$ & 0,723 & $7(19.4)$ & $7(19.4)$ & 1.000 \\
\hline Severe & $0(0.0)$ & $0(0.0)$ & 1.000 & $0(0.0)$ & $0(0.0)$ & 1.000 \\
\hline \multicolumn{7}{|l|}{ Breathiness } \\
\hline Normal & $13(33.3)$ & $9(23.1)$ & 0,314 & $10(27.8)$ & $13(36.1)$ & 0,448 \\
\hline Mild & $15(38.5)$ & $26(66.7)$ & $0.013^{*}$ & $16(44.4)$ & $11(30.6)$ & 0,224 \\
\hline Moderate & $11(28.2)$ & $4(10.3)$ & $0.044^{*}$ & 8 (22.2) & $11(30.6)$ & 0,422 \\
\hline Severe & $0(0.0)$ & $0(0.0)$ & 00 & $2(5.6)$ & $1(2.8)$ & 0,555 \\
\hline \multicolumn{7}{|l|}{ Asthenia } \\
\hline Normal & $34(94.4)$ & 32 (88.9) & 0,394 & 36 (92.3) & 36 (92.3) & 1.000 \\
\hline Mild & $1(2.8)$ & $3(8.3)$ & 0,303 & $3(7.7)$ & $3(7.7)$ & 1.000 \\
\hline Mod & $1(2.8)$ & $1(2.8)$ & & $(0.0)$ & $0(0.0)$ & 1.000 \\
\hline Severe & $0(0.0)$ & $0(0.0)$ & 1.000 & (0.0) & $0(0.0)$ & 1.000 \\
\hline \multicolumn{7}{|l|}{ Strain } \\
\hline Normal & $24(61.5)$ & $31(79.5)$ & 0,082 & $24(66.7)$ & $25(69.4)$ & 0.800 \\
\hline Mild & $10(25.6)$ & $6(15.4)$ & 0,262 & $10(27.8)$ & $10(27.8)$ & 1.000 \\
\hline Moderate & 4 (10.3) & $1(2.6)$ & 0,165 & $1(2.8)$ & $1(2.8)$ & 1.000 \\
\hline Severe & $1(2.6)$ & $1(2.6)$ & 1.000 & $1(2.8)$ & $0(0.0)$ & ,314 \\
\hline \multicolumn{7}{|l|}{ Instability } \\
\hline Normal & 34 (87.2) & $31(79.5)$ & 0,362 & $24(66.7)$ & $28(77.8)$ & 0,293 \\
\hline Mild & $5(12.8)$ & $8(20.5)$ & 0,362 & $10(27.8)$ & 8 (22.2) & 0,586 \\
\hline Moderate & $0(0.0)$ & $0(0.0)$ & 1.000 & $2(5.6)$ & $0(0.0)$ & 0,151 \\
\hline Severe & $0(0.0)$ & $0(0.0)$ & 1.000 & $0(0.0)$ & $0(0.0)$ & 1.000 \\
\hline
\end{tabular}

*Significant values $(p<0.05)$ - Mann-Whitney's test

Caption: $\mathrm{DTG}=$ direct training group; $\mathrm{ITG}=$ indirect training group
Language Pathology and Audiology students of the University of $\mathrm{Gent}^{(4)}$. These data, among others, lead the researchers to foster the implementation of voice training to minimize the vocal risks in these future voice professionals ${ }^{(4-7)}$.

Differences were observed in the auditory perceptual analysis of the sustained vowel only for the DTG, which showed less voice deviations in the post-training (Table 3). It is interesting to note that in a group of Speech Language Pathology and Audiology students, with voices supposedly considered neutral, $41 \%$ of sustained vowel emissions showed some deviation to a moderate degree. The reduction of voice deviations from moderate to mild shows the positive effect of direct vocal training in this group. A study with teachers undergoing vocal training with direct approach showed a significant reduction in the degree of strain, both in the auditory perceptual analysis of the vowel $/ \varepsilon /$ and in the analysis of spontaneous speech of these professionals ${ }^{(29)}$. The ITG remained similar pre- and post-training, as expected, because it was not submitted to vocal training.

No differences were observed in the auditory perceptual analysis of speech in both groups (Table 4). According to the literature, the auditory perceptual assessment of the sustained vowel differs from that of the connected speech, as it seeks to

Table 4. Measures of the scores of the perceptual evaluation of connected speech

\begin{tabular}{|c|c|c|c|}
\hline & DTG & ITG & \multirow{2}{*}{$\mathrm{p}$-value } \\
\hline & $\mathrm{n}(\%)$ & $\mathrm{n}(\%)$ & \\
\hline \multicolumn{4}{|l|}{ Counting } \\
\hline Better post-training & $9(23.1)$ & $20(55.6)$ & 0,060 \\
\hline Better pre-training & $20(55.6)$ & $10(27.8)$ & 0,228 \\
\hline Similar & $10(27.8)$ & $6(16.7)$ & 0,060 \\
\hline \multicolumn{4}{|c|}{ Articulation and pronunciation } \\
\hline Similar & $6(16.7)$ & $23(63.9)$ & \multirow{2}{*}{0,160} \\
\hline Better & $23(63.9)$ & $13(36.1)$ & \\
\hline \multicolumn{4}{|c|}{ Pneumophonoarticulatory coordination } \\
\hline Similar & $13(36.1)$ & $31(86.1)$ & \multirow{2}{*}{0,385} \\
\hline Better & $31(86.1)$ & $5(13.9)$ & \\
\hline \multicolumn{4}{|l|}{ Loudness } \\
\hline Similar & $5(13.9)$ & $30(83.3)$ & \multirow{2}{*}{0,232} \\
\hline Better & 30 (83.3) & $6(16.7)$ & \\
\hline \multicolumn{4}{|l|}{ Pitch } \\
\hline Similar & $6(16.7)$ & $35(97.2)$ & \multirow{2}{*}{0,195} \\
\hline Better & $35(97.2)$ & $1(2.8)$ & \\
\hline \multicolumn{4}{|l|}{ Vocal quality } \\
\hline Similar & $1(2.8)$ & $25(69.4)$ & \multirow{2}{*}{0,117} \\
\hline Better & $25(69.4)$ & $11(30.6)$ & \\
\hline \multicolumn{4}{|l|}{ Resonance } \\
\hline Similar & $11(30.6)$ & $30(83.3)$ & \multirow{2}{*}{0,883} \\
\hline Better & 30 (83.3) & $6(16.7)$ & \\
\hline \multicolumn{4}{|c|}{ Use of emphasis and melody } \\
\hline Similar & $6(16.7)$ & $33(91.7)$ & \multirow{2}{*}{0,066} \\
\hline Better & $33(91.7)$ & $3(8.3)$ & \\
\hline \multicolumn{4}{|l|}{ Speech rate } \\
\hline Similar & $3(8.3)$ & $29(80.6)$ & \multirow{2}{*}{0,701} \\
\hline Better & $29(80.6)$ & $7(19.4)$ & \\
\hline
\end{tabular}

*Significant values $(p<0.05)$ - Test of Equality of Proportions

Caption: $\mathrm{DTG}=$ direct training group; $\mathrm{ITG}$ = indirect training group 
show mild changes that are not perceived in connected speech, a type of issue that just masks such changes, as occurred in this study ${ }^{(30)}$.

In the acoustic analysis of the SRP and VRP (Table 5), positive effects were observed only for the DTG, with greater amplitude of maximum frequency, frequency range, and semitone range in the SRP; and greater amplitude of maximum frequency, frequency range, and area in the VRP.

Table 5. Comparison between the performances of the groups for Acoustic Analysis Gain in the Speech Range Profile and Vocal Range Profile

\begin{tabular}{|c|c|c|c|c|}
\hline \multirow{2}{*}{ Parameter } & \multicolumn{2}{|l|}{ SRP } & \multicolumn{2}{|l|}{ VRP } \\
\hline & Mean (SD) & $p$-value & Mean (SD) & $\mathrm{p}$-value \\
\hline \multicolumn{5}{|l|}{ Minimum F0 } \\
\hline DTG $(n=13)$ & $-1.97(42.81)$ & \multirow{2}{*}{0,663} & $1.86(67.07)$ & \multirow{2}{*}{0,744} \\
\hline ITG $(n=12)$ & $0.10(19.71)$ & & $5.35(66.48)$ & \\
\hline \multicolumn{5}{|l|}{ Maximum F0 } \\
\hline DTG $(n=13)$ & $138.25(249.81)$ & \multirow{2}{*}{$0.008^{*}$} & $58.30(73.20)$ & \multirow{2}{*}{$0.030^{*}$} \\
\hline ITG $(n=12)$ & $-63.75(169.08)$ & & $-61.74(132.67)$ & \\
\hline \multicolumn{5}{|l|}{ F0 range } \\
\hline DTG $(n=13)$ & $140.22(243.07)$ & \multirow{2}{*}{$0.014^{\star}$} & 54.91 (96.22) & \multirow{2}{*}{$0.030^{*}$} \\
\hline ITG $(n=12)$ & $-63.84(171.44)$ & & $-67.05(147.14)$ & \\
\hline \multicolumn{5}{|l|}{ ST range } \\
\hline DTG $(n=13)$ & $5.28(8.53)$ & \multirow{2}{*}{$0.039^{\star}$} & 2.22 (10.89) & \multirow{2}{*}{0,301} \\
\hline ITG $(n=12)$ & $-2.43(7.38)$ & & $-2.69(10.62)$ & \\
\hline \multicolumn{5}{|c|}{ Minimum intensity } \\
\hline DTG $(n=13)$ & $0.00(0.13)$ & \multirow{2}{*}{0,644} & $1.38(3.62)$ & \multirow{2}{*}{0,192} \\
\hline ITG $(n=12)$ & $-3.74(6.03)$ & & $-2.79(7.33)$ & \\
\hline \multicolumn{5}{|c|}{ Maximum intensity } \\
\hline DTG $(n=13)$ & $-1.34(12.21)$ & \multirow{2}{*}{0,073} & $-1.37(12.67)$ & \multirow{2}{*}{0,073} \\
\hline ITG (n=12) & $-10.37(17.22)$ & & $-10.62(19.02)$ & \\
\hline \multicolumn{5}{|l|}{ Area } \\
\hline DTG $(n=13)$ & $0.41(2.71)$ & \multirow{2}{*}{0,092} & $0.29(1.41)$ & \multirow{2}{*}{$0.028^{*}$} \\
\hline ITG $(n=12)$ & $-1.62(2.93)$ & & $-0.35(0.69)$ & \\
\hline
\end{tabular}

*Significant values $(p<0.05)-$ Mann-Whitney's test

Caption: $\mathrm{DTG}=$ direct training group; $\mathrm{ITG}$ = indirect training group; $\mathrm{SRP}=$ Speech Range Profile; VRP = Vocal Range Profile; $\mathrm{SD}=$ standard deviation; $\mathrm{ST}=$ semitone

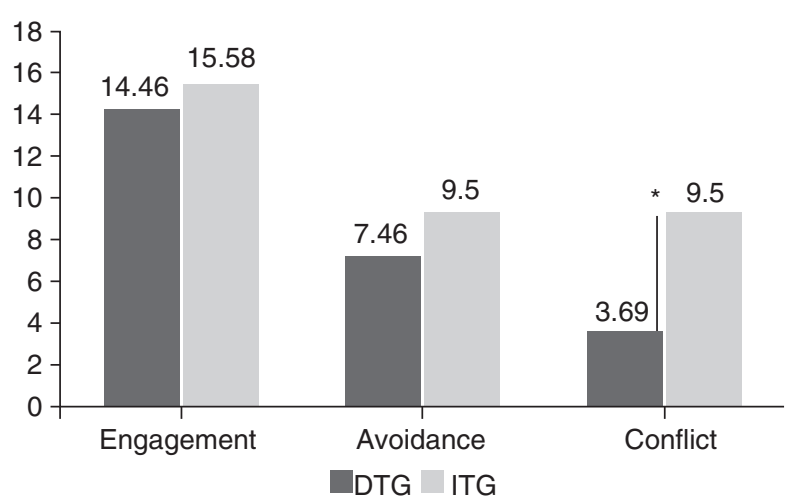

*Significant value ( $p$-value $=0.006)-$ Mann-Whitney's test Caption: DTG = direct training group; ITG = indirect training group Figure 1. Comparison between the responses of the Group Climate Questionnaire for each group of the vocal training applied to Speech Language Pathology and Audiology undergraduates
These findings prove a better vocal performance for the direct training group. However, the ITG had reduced results, which shows the low impact of the vocal guidance in specific parameters evaluated by such acoustic analysis, when used in isolation.

Similar results were observed in a study with Speech Language Pathology and Audiology students ${ }^{(6)}$, in which the students were submitted to vocal warm-up exercises. Research has shown a better performance of individuals in the post-training moment, measured by the acoustic analysis, with reduction in the intensity and greater amplitude of the vocal frequency. In another study, indirect approach training applied to Speech Language Pathology and Audiology students was important for the modification of vocal behaviors such as screaming, reduction of general fatigue, and decreased voice complaints ${ }^{(7)}$, habits that are directly related to the topics addressed in this type of training.

The analysis of the responses of the Group Climate Questionnaire (Figure 1) showed differences between groups only in the conflict score, which was higher for the ITG. This can be explained by the characteristics of the indirect approach training applied to this group, with less chance of interactional exchanges, demanding a more passive stance by the participant, who acts only as a listener of the vocal guidance. However, the direct approach led to increased exchange with the practical exercises, showing less conflict at the end of the sessions. Some studies have found that the results and the success of collective interventions may be related to the type of group climate. It was observed that, when there is a negative group interaction, with individuals in conflict or avoidance, there is a significant reduction in quality of life, with increased vocal symptoms and low adhesion to the treatment ${ }^{(18,19)}$. Thus, the approach used in the DTG led to a more active attitude and provided a better group climate among the members, with less conflict.

In short, direct approach training, consisting of vocal exercises, can provide a change in vocal functioning ${ }^{(8)}$, with reduced vocal intensity and increased fundamental frequency ${ }^{(6)}$; expansion of frequency range with better range of low and high sounds, and vocal intensity with better range of weak and strong sounds ${ }^{(10)}$; better articulation pattern and fluency of speech ${ }^{(11)}$; and reduced jitter ${ }^{(12)}$. However, the indirect approach can help the individual to understand vocal use ${ }^{(8)}$ and prevent worsening of vocal symptoms ${ }^{(12)}$. However, research shows that the indirect approach may not represent an immediate impact on the vocal tract ${ }^{(13,14)}$.

The limitation of this study was the small sample size due to the low adherence of students to training, justified by the lack of knowledge on the importance and benefits of voice training. It is suggested that a combined approach should be used to check the effect of the three types of training suggested in the literature: indirect approach, direct approach, and combination approach.

This study may serve as inspiration to Speech Language Pathology and Audiology courses, so that vocal training programs are incorporated in the graduation to promote vocal health and to prevent dysphonia. 


\section{CONCLUSION}

The participants of voice training subjected to a direct approach, with vocal exercises, benefited from the training offered, which impacted positively on various voice analysis dimensions. However, the indirect approach, only with vocals guidelines, was not sufficient to produce significant changes in the vocal quality of the students, who took a more passive attitude toward the guidelines.

*MB was the advisor and was responsible for the research design and correction of the manuscript; $M C M B$ was the co-advisor and responsible for the research and correction of the manuscript; ACMS was responsible for research, organization, and analysis of the database, and drafting of the manuscript.

\section{REFERENCES}

1. Stival N, Mello JM. O ensino superior e a fonoaudiologia no Brasil. In: Ribas A, Pazini S. (orgs.). Fonoaudiologia e educação: uma parceria necessária. Curitiba: UTP; 2010. p. 82:87.

2. Behlau M, Feijó D, Madazio G, Rehder MI, Azevedo R, Ferreira AE. Voz profissional: Aspectos gerais e atuação Fonoaudiológica. In: Behlau M. Voz o livro do especialista II. São Paulo: Revinter; 2010. p.311-333.

3. Bicalho AD, Behlau M, Oliveira G. Termos descritivos da própria voz: comparação entre respostas apresentadas por fonoaudiólogos e nãofonoaudiólogos. Rev CEFAC. 2010;12 (4):543-50.

4. Van Lierde K, D'Haeseleer E, Wuyts F, de Ley S, Geldof R, De Vuyst J, et al. The objective vocal quality, vocal risk factors, vocal complaints, and corporal pain in Dutch female students training to be speech-language pathologists during the 4 years of study. J Voice. 2010;24(5):592-8.

5. Gottliebson RO, Lee L, Weinrich B, Sanders JR. Voice problems of future speech-language pathologists. J Voice. 2007;21(6):699-704.

6. Van Lierde K, D'haeseleer E, Baudonck N, Claeys S, De Bodt M, Behlau M. The impact of vocal warm-up exercises on the objective vocal quality in female students training to be Speech Language Pathologists. J Voice. 2011;25(3):115-21.

7. Van Lierde K, D'haeseleer E, Deley S, Luyten A, Baudonck N, Claeys $\mathrm{S}$, et al. The impact of a voice counseling procedure to select students with normal vocal characteristics for starting a Master Program in Speech Language Pathology: a pilot study. J Voice. 2012;26(5):623-8.

8. Anhaia TC, Gurgel LG, Vieira RH, Cassol M. Intervenções vocais diretas e indiretas em professores: revisão sistemática da literatura. ACR. 2013; 18(4):361-6.

9. Rodríguez-Parra MJ, Adria JA, Casado JC. Comparing voice-therapy and vocal-hygiene treatments in dysphonia using a limited multidimensional evaluation protocol. J Commun Dis. 2011;44:615-30.

10. LeBorgne WD, Weinrich BD. Phonetogram Changes for trained singers over a nine-month period of vocal training. J Voice. 2012;16(1):37-43.

11. Moreira TC, Cassol M, Fávero SR, Oliveira LB, Longaray CS, Soares $\mathrm{MO}$, et al. Intervenção fonoaudiológica para consultores em um serviço de teleatendimento: bem-estar vocal. Rev CEFAC. 2010;12(6):936-44.
12. Oliveira AG, Gouveia N, Behlau M. The effectiveness of a voice training program for telemarketers. J Voice. 2012;26(6):815e1-8.

13. Nanjundeswaran C, Ii NY, Chan KM, Wong RK, Yiu EM, Verdolini-Abbott $\mathrm{K}$. Preliminary data on prevention and treatment of voice problems in student teachers. J Voice. 2012;26(6):816e1-12.

14. Bovo R, Galceram M, Petrucelli J, Hatzopoulos S. Vocal problems among teachers: evaluation of a preventive voice program. J Voice. 2007;21(6):705-22.

15. Araújo MLB, Freire RMAC. Atendimento fonoaudiológico em grupo. Rev CEFAC. 2011;13(2):362-38.

16. Camargo AM, Silva APBV, Wolff LDG, Soares VMN, Gonçalves CGO. Abordagens grupais em Saúde Coletiva: a visão de usuários e de profissionais de enfermagem. Rev Bras Ciênc Saúde. 2012;10(31):1-9.

17. Ribeiro VV, Panhoca I, Dassie-Leite AP, Bagarollo MF. Grupo terapêutico em Fonoaudiologia: revisão de literatura. Rev CEFAC. 2012;14(3):544-52.

18. MacKenzie KR. The clinical application of a group climate measure. In: Dies RR, MacKenzie KR. Advances in group Psychotherapy: Inter-grating research and practice. New York: International Universities Press; 1983 p. 159-70.

19. Law T, Lee KY, Ho FN, Vlantis AC, Van Hasselt AC, Tong MC. The. effectiveness of group voice therapy: a group climate perspective. J Voice. 2012;26(2):41-8.

20. Deary IJ, Wilson JA, Carding PN, MacKenzie K. VoiSS: a patient-derived: Voice Symptom Scale. J Psychosom Res. 2003;54(5):483-9.

21. Moreti F, Zambon F, Oliveira G, Behlau M. Cross-Cultural adaptation, validation, and cutoff values of the brazilian version of the Voice Symptom Scale - VoiSS. J Voice. In press 2014.

22. Hirano M. Clinical Examination of Voice. New York: Springer Verlag; 1981.

23. Moraes MC, Behlau MS. Perfil de extensão de fala e de voz na clínica vocal [Internet]. In: $18^{\circ}$ Congresso Brasileiro de Fonoaudiologia; 2010 Set 22-25; Curitiba. Anais. São Paulo: SBFa; 2010. Available from: http:// www.sbfa.org.br/portal/suplementorsbfa

24. Behlau M, Madazio G, Feijo D, Azevedo R, Gielow I, Rehder MI. Aperfeiçoamento vocal e tratamento fonoaudiólogo das disfonias. In: Behlau M. Voz: O Livro do Especialista - Volume II. Rio de Janeiro: Revinter; 2010. p.410-565.

25. Faria DM, Camisa MT, Guimarães MA. Muito além do ninho de mafagafos: um guia de exercícios práticos para aprimorar sua comunicação. São Paulo: J\&H Editoração; 2011.

26. Behlau M (org). Voz: O Livro do Especialista - Volume I. Rio de Janeiro: Revinter; 2008.

27. Hazlett DE, Duffy OM, Moorhead SA. Review of the impact of voice training on the vocal quality of professional voice users: implications for vocal health and recommendations for further research. J Voice. 2011;25(2):181-91.

28. Silva RSA, Simões-Zenari M, Nemr NK. Impacto de treinamento auditivo na avaliação perceptivo-auditiva da voz realizada por estudantes de Fonoaudiologia. J Soc Bras Fonoaudiol. 2012;24(1):19-25.

29. Silverio KCA, Gonçalves CGO, Penteado RZ, Vieira TPG, Libardi A, Rossi D. Ações em saúde vocal: proposta de melhoria do perfil vocal de professores. Pró-Fono R Atual Cient. 2008;20(3):177-82.

30. Behlau M, Madazio G, Feijo D, Pontes P. Avaliação de Voz. In: Behlau M. Voz: o livro do especialista. Vol. I. Rio de Janeiro: Revinter; 2008; p.85-246. 
Appendix 1. Group climate questionnaire

\section{QUESTIONÁRIO DE CLIMA DE GRUPO \\ GROUP CLIMATE QUESTIONNAIRE-SHORT FORM (GCQ-S)}

MacKenzie, 1993 - traduzido e adaptado culturalmente para o Português Brasileiro pelos autores

Avalie as afirmações abaixo do questionário e responda de acordo com a escala de 0 (nem um pouco) a 6 (totalmente) em relação ao grupo que você participou.

Escala de respostas de 0 (nem um pouco) a 6 (totalmente)

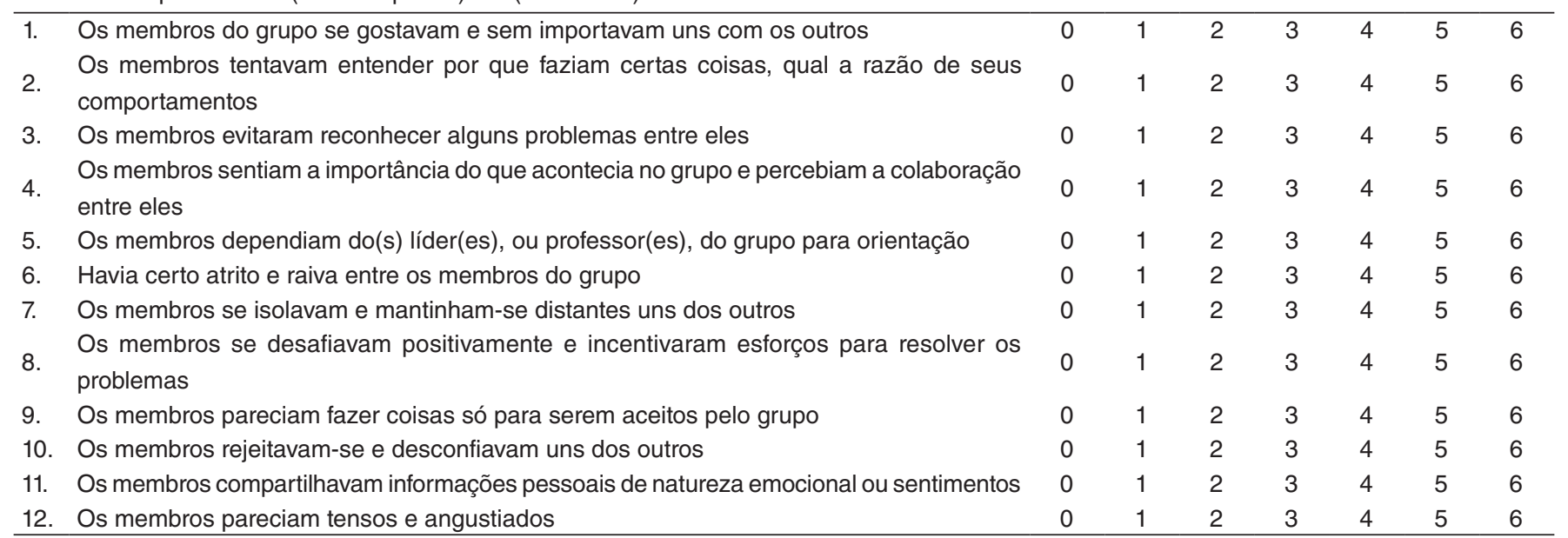

Engajamento: questões 1, 2, 4, 8, 11

Evitação: questões 3, 5, 9

Conflito: questões 6, 7, 10, 12

Referência apresentada: MacKenzie KR. The clinical application of a group climate measure. In: Dies RR, MacKenzie KR (eds). Advances in group psychotherapy: inter-grating research and practice. New York: International Universities Press; 1983. p. $159-70$ 